\title{
HEMOLYTIC ACTIVITY OF STAPHYLOCOCCUS HYICUS AND STAPHYLOCOCCUS CHROMOGENES
}

\author{
B. SKALKA
} Department of Epizootiology, Microbiology and Immunology,
University of Veterinary Science, 61242 Brno

Received February 26, 1988

A b s $t r a c t$

$S k$ a 1 k a B.: Hemolytic activity of Staphylococcus hyicus and Staphylococcus chromogenes. Acta vet. Brno, 57, 1988: 3-11.

Hemolytic activity of 135 S. hyicus and 75 S. chromogenes strains was examined on sheep, rabbit, human, horse and chicken blood agars. The agar bases were supplemented with $5 \%$ washed erythrocytes of the corresponding animal species. The strains of both staphylococcal species under study produced a wide zone of complete hemolysis on rabbit blood agar and a narrow one on media containing horse erythrocytes. The hemolytic effects always appeared after $48 \mathrm{~h}$ incubation at $37^{\circ} \mathrm{C}$. Neither species produced hemolysis on agar containing sheep or chicken erythrocytes, and no synergistic hemolytic effect was observed on sheep blood agar. A direct hemolysis was exhibited by $92(68 \%) \quad$ S. hyicus strains on human blood agars. The remaining $\underline{S}$. hyicus strains and $\underline{S}$. chromogenes did not produce hemolysis of human erythrocytes. Hemolytic effects of the staphylococci used as controls were expressed just after $24 \mathrm{~h}$ incubation on all kinds of blood agar. We recommend inclusion of the hemolysis of rabbit erythrocytes among the characteristic properties of $\underline{S}$ hyicus and $\underline{S}$. chromogenes.

Staphylococcus hyicus, Staphylococcus chromogenes, hemolytic activity, blood agar, sheep, rabbit, human, horse and chicken erythrocytes.

Staphylococcus hyicus (B a i r d - P a r k e r 1965), originally named Micrococcus hyicus (S o m p o 1 i $n^{*} s k$ y 1953), was subdivided in two subspecies, namely subsp. hyicus and subsp. chromogenes (D e v r i e $s$ e et al. 1978; $K 1 \circ \circ \mathrm{s}$ and $\mathrm{S} c \mathrm{~h} 1$ e $\mathrm{i} f \mathrm{e} \mathrm{r}$ 1986), but these were later elevated to species status: $S$. hyicus and $S$. chromogenes $(H$ á $j$ e $k$ et al. 1986). Lack of hemolysis of sheep red blood cells is one of the most important properties of both $\underline{S}$. hyicus and $S$. chromogenes (D e $v$ ri e s e 1977; D e $v$ r $i$ e $s$ et al. 1978; $H$ á $j$ e $k$ et al. 1986; $K 1 \circ \circ \mathrm{s}$ and $S$ c $h$ 1 e $i$ f e r 1986; $S k$ a $1 k$ a 1987). It is well established that intact sheep erythrocytes are relatively insensitive to hemolysins elaborated by staphylococci of both coagulase-positive and coagulase-negative species (M $a r k s$ and $V$ a $u g$ a $n$ 1950; $B$ e $n h$ e $m$ e r et al. 1968; $W i$ s e $m$ a $n$ 1975). Nevertheless, their subceptibility increases remarkably if the cell membrane sphingomyelin is disintegrated by the beta-toxin of s. aureus (C h r $i \mathrm{~s} t \mathrm{i}$ and $\mathrm{G}$ r y d o n 1941; A d a m c y k and 
B 1 a u r o c k 1963; S k a 1 k a et a1. 1979a; 1979b; B o y c e 1985), or by the toxin of Corynebacterium pseudotuberculosis ( $S \circ u$ c e $k$ et al. 1967; S k a 1 k a et al. 1979b; 1980). Such a phospholipase-conditioned hemolysis, called synergistic hemolysis, is characteristic of staphylococcal delta-1ysin ( $\mathrm{h} r \mathrm{i} \mathrm{s} i \mathrm{e}$ and $\mathrm{G}$ a y d o n 1941; A d a m c z y k and $B \quad 1$ a $r$ o c k 1963). $H$ é b e r t and $H$ a n c o c $k$ (1985) and $\mathrm{W} a \mathrm{t} s$ and $0 \mathrm{w}$ e $\mathrm{n} s$ (1987) observed some synergistic hemolytic phenomenon produced by a limited number of $\underline{S}$. hyicus and $\underline{S}$. chromogenes strains. On the other hand, the red blood cells of other animal species show greater susceptibility to some bacterial hemolytic substances, so that human ( $W$ i $\mathrm{s} m$ a $n$ and $\mathrm{C}$ a $\mathrm{i}$ r 1968; $W$ i s e m a $\mathrm{n}$ 1975; $\mathrm{K} 10$ o $s$ and $S$ c h 1 e $i$ e r 1986), rabbit (C o o p e r et al. 1964; B e r n h e i m e r 1965; W i s e m a n 1975; F a c k e 11 and $w i$ s e m a n 1976), horse ( $G$ y $\circ \mathrm{n} \mathrm{e} t$ and $P 1 \circ \mathrm{m} \mathrm{me} \mathrm{1970),} \mathrm{and}$ poultry erythrocytes ( $M \quad \ddot{o} 1 \quad 1 \quad b \quad y$ and $W$ a $d s \quad t \quad r \quad \ddot{m}$ 1971) are recommended for detection of the hemolysins produced by staphylococci.

The present paper is devoted to study the behaviour of $S$. hyicus and $S$. chromogenes in media supplemented with red blood cells of different animal species and to examine the possible synergistic hemolysis of $\underline{S}$. hyicus and S. chromogenes against sheep erythrocytes.

Materia 1 s a nd Met hod s

Agar medium

Brain heart infusion agar CM 375 (Oxoid Ltd) was used.

Erythrocytes

Sheep, rabbit, human, horse and pultry (Gallus domesticus) erythrocytes were used. For detection of hemolysis, the agar base described above was supplemented with $5 \%(v / v)$ erythrocytes, washed three times, of the corresponding animal species.

Bacteria

The identification procedure described by $\mathrm{K} 100 \mathrm{~s}$ and $\mathrm{S} \mathrm{ch} 1 \mathrm{e}$ i f e r (1986) was used for all staphylococcal strains.

Strain for the synergistic (phospholipase-conditioned) hemolysis

Staphylococcus aureus CCM 6188 producing beta toxin (phospholipase C) was employed for disintegration of sphingomyelin of sheep erythrocytes.

Investigated organisms

The assays were carried out with 135 Staphylococcus hyicus strains, including CCM 2368, 75 Staphylococcus chromogenes strains, including CCM 3387, and 5 strains which were not allocated to any staphylococcal species. The properties of the strains of both species corresponded with those

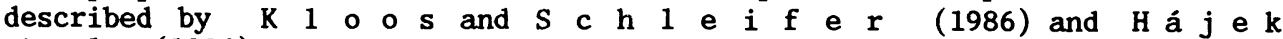
et al. (1986), except that 46 strains of S. hyicus were non-proteolytic and only 38 S. chromogenes strains produced pigment. The non-allocated strains shared characteristics of $\mathrm{S}$. hyicus, namely the strong Tween 80 splitting and the proteolytic activity, but they did not elaborate hyaluronidase.

Control organisms

The following staphylococcal species were used for control purposes: 10 strains of S. aureus, including CCM 2351 producing alpha-toxin, and CCM 2512 producing delta-hemolysin; 10 strains of $\mathrm{S}$. epidermidis, including CCM $2124 ; 8$ srains of $S$. haemolyticus, including CCM $2737 ; 3$ strains of S. caprae; 5 strains of $\underline{S}$. hominis, including CCM $3474 ; 6$ strains of $\underline{\text {. }}$ simulans, including CCM 2705; 3 strains of S. warneri, including CCM 2730. 
at $37^{\circ} \mathrm{C}$, and the result was read after $24 \mathrm{~h}, 48 \mathrm{~h}$, and $72 \mathrm{~h}$. The direct hemolysis and the hemolytic effect on phospholipase-treated erythrocytes were evaluated on sheep blood agar as described previously ( $\mathrm{S} \mathrm{k}$ a $1 \mathrm{k}$ a et a1. 1979a; 1979b). The other blood agars served merely for demonstration of the direct hemolysis.

\section{$R$ e s u l t s}

Three S. aureus strains, including CCM 2351, proved to be strongly hemolytic on sheep blood agar, as appeared in the direct effect, but the wide hemolysis surrounding the streaks was reduced in the zone of the beta-hemolysin. Such antagonism of hemolysis is characteristic of those $S$. aureus strains which produce alpha-toxin and only a negligible amount of delta-hemolysin. Seven $S$. aureus strains, including CCM 2512, produced narrower, sometimes indistinct, hemolytic zones as a direct effect, and these zones were always considerably enhanced when erythrocytes were affected by the beta-hemolysin. This synergistic hemolysis is characteristic of staphylococcal delta-hemolysin. The hemolytic activity of 7 S. epidermidis strains, 8 S. haemolyticus 2 S. caprae, $2 \underline{\mathrm{S} .}$ hominis, 2 S. simulans, and 1 S. warneri strain was the same as of $\underline{S}$. aureus delta-hemolysin producing strains. These hemolytic effects were apparent just after $24 \mathrm{~h}$ incubation (Fig. 1). The remaining strains of coagulase-negative staphylococcal species grew without any direct or synergistic hemolysis (non-hemolytic group - NHG) on sheep blood agar. The strains of S. hyicus, $S$. chromogenes, and of the non-allocated staphylococci did not show direct or synergistic hemolysis on sheep blood agar after $24 \mathrm{~h}, 48 \mathrm{~h}$, and $72 \mathrm{~h}$ incubation (Fig. 1). However, after 48 to 72 hours' incubation, a narrow zone of incomplete clearing appeared around inoculation streaks of some strains under study in the zone of activity of the staphylococcal beta-hemolysin. The occurrence of this phenomenon was occasional and its reproducibility was very low.

A wide zone of complete hemolysis appeared around the streaks of three alpha-toxin positive $S$. aureus strains on rabbit blood agar after $24 \mathrm{~h}$ incubation, and the diameter of the hemolytic effect increased considerably with further incubation (Fig. 2; Fig. 3). The remaining control strains of $\mathrm{S}$. aureus and those of coagulase-negative species, which were hemolytic on sheep blood agar, also hemolyzed rabbit blood agar, producing narrower zones of hemolysis than the 
alpha-toxin strains, with only a slight increase in diameter on prolonged incubation (Fig. 2; Fig. 3). The NHG strains did not produce hemolysis on rabbit blood agar. An unusual phenomenon was observed when the strains of $\underline{S}$. hyicus, S. chromogenes, and of the group of non-allocated staphylococci grew on rabbit blood agar. No hemolysis appeared around the streaks of the strains under study after $24 \mathrm{~h}$ incubation (Fig. 2; Fig. 4). However, a broad zone of complete hemolysis was produced by all strains within a further $24 \mathrm{~h}$ (Fig. 3 ; Fig. 5). This singular delayed hemolysis, appearing after $48 \mathrm{~h}$ incubation, was reproducibly shown by all strains under study.

A complete hemolysis of human erythrocytes developed around the growth of $\underline{S}$. aureus strains and of coagulase-negative staphylococci, which were hemolytic on sheep and rabbit blood agars. The effect was shown after $24 \mathrm{~h}$ incubation. The zone of clearing produced by three alpha-toxin strains was less intense than that caused by the producers of delta-hemolysin and the coagulase-negative strains with hemolytic properties (Fig. 6). The NHG strains did not hemolyze on human blood agar. The hemolytic reaction was seen with $92(68 \%)$ strains of $\underline{S}$. hyicus after $48 \mathrm{~h}$ incubation. The hemolysis was not as wide as the zones produced by other hemolytic staphylococci (Fig. 6). The remaining strains of $\underline{S}$. hyicus, and all strains of $\underline{S}$. chromogenes, did not show hemolysis on human blood agar.

On agar containing horse erythrocytes, a wide zone of complete hemolysis with sharp edges surrounded as the streaks of delta-hemolysin $S$. aureus strains, as the growth of the hemolytic coagulase-negative staphylococci. A smaller zone with blurred edges surrounded the streaks of three alpha-toxin strains. Both effects were developed after 24 $h$ incubation. $\underline{S}$. hyicus, $\underline{S}$. chromogenes, and the non-allocated strains produced a very narrow complete hemolysis on this medium after $48 \mathrm{~h}$ incubation (Fig. 7). The NHG strains grew without hemolysis on horse blood agar.

All hemolytic strains of staphylococci used as controls produced wide zone of complete hemolysis on agar containing chicken erythrocytes. S. hyicus, S. chromogenes, the non-allocated strains, and the NHG staphylococci grew without hemolysis on this blood agar (Fig. 8). 


\section{D i s c u s s i o n}

The detection of hemolytic activity, especially on sheep blood agar, is a significant component of detailed diagnosis of many bacterial species, or of some strains within a species. The production of hemolysin(s) provides an important marker in the identification of staphylococci. In view of this fact, it is therefore important to specify which of the known hemolysins is produced ( $M$ a $r \mathrm{k}$ and $V$ a $\mathrm{u} \mathrm{h} \mathrm{a} \mathrm{n}$ 1950;

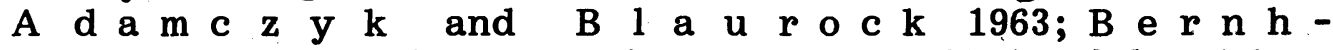
e i m e r et al. 1968; W i s e m a n 1975; S k a $1 \mathrm{k}$ a et al. $1979 a ; 1979 b ; 1980 ;$ B o y $c$ e $1985 ;$ H é b e r t and $\mathrm{H}$ a n c o c k 1985; $\mathrm{K} l$ o $o$ s and $S \mathrm{chle}$ if e r 1986; $\mathrm{W}$ a t $\mathrm{t}$ and $\mathrm{O}$ w e $\mathrm{n}$ s 1987). Nevertheless, hemolytic inactivity constitutes a feature of diagnostic value, for example for $S$. hyicus and $S$. chromogenes (D e v ri e $s$ et al. 1978; $\mathrm{H}_{\mathrm{a}} \mathrm{j}$ e $\mathrm{k}$ et al. 1986; K 1 o o $\mathrm{s}$ and $S$ c $h$ l e i f e $r$ 1986). Some strains of $S$. aureus, however, especially those of the ecovar $B$, do not produce hemolysin either, and lack of hemolysis of some $\mathbf{S}$. intermedius strains has also been described ( $\mathrm{S}$ k a $1 \mathrm{k}$ a et al. 1979a; 1980). In addition, hemolytic strains in many coagulase-negative species are known ( $\mathrm{h} r \mathrm{i} s \mathrm{t} e$ and $G$ a y d o $n$ 1941; $\mathrm{H}$ é $\mathrm{b}$ e $\mathrm{r} t$ and $\mathrm{H}$ a $\mathrm{n}$ c o c k 1985; K loo $\mathrm{s}$ and $\mathrm{S}$ c $\mathrm{h} 1$ e i f e r 1986; W a t $\mathrm{s}$ and $\mathrm{O}$ w e $\mathrm{n}$ s 1987). Hemolysis of those strains on sheep blood agar is usually weak, but becomes stronger if red blood cells of other animal species ( $M$ a $\quad k \quad s$ and $V a$ a $h$ a 1950) or the synergistic (phospholipase-conditioned) hemolysis (A d a m c $\mathrm{z}$ y $\mathrm{k}$ and $\mathrm{B} \mathrm{l}$ a u r o c $\mathrm{k}$ 1963) are employed.

The hemolytic effects of coagulase-positive and coagulase-negative staphylococci used for control in the present study agreed with the descriptions of other authors ( $M$ a $r$ s and $V$ a $u$ g h a $n$ 1950; J a c $k$ s o $n$ 1962; A d a m c $\mathrm{z}$ y $\mathrm{k}$ and $\mathrm{B} 1$ a $\mathrm{u}$ r o c k 1963; C o o p e r et al. 1964; $B$ e $r \mathrm{n}$ e $\mathrm{i} m$ e $r$ 1965; W i s e m a $n$ 1975; $W$ i s e $m$ a $n$ and $C$ a i r d 1976; $B$ o y c e 1985;

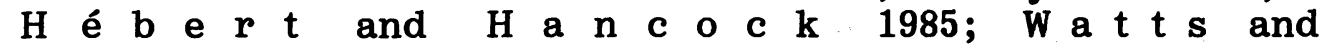
$\mathrm{O}$ w e $n \mathrm{~s}$ 1987) and with our previous experience as well ( $\mathrm{k}$ a l k a et al. 1979a; 1979b; 1980).

The inability of $S$. hyicus and $S$. chromogenes to produce the direct hemolysis of the intact sheep red blood cells (S o m p o li n s k y 1953; B a i r d - P a r k e r 1965; $\mathrm{D}$ e $\mathrm{v}$ r i e s e 1977; $\mathrm{D}$ e v r i e s e et al. 1978; H á j e $\mathrm{k}$ et al. 1986; $\mathrm{K} l \circ$ o $\mathrm{s}$ and $\mathrm{S}$ c $\mathrm{h} l$ e i f e $\mathrm{r}$ 1986) 


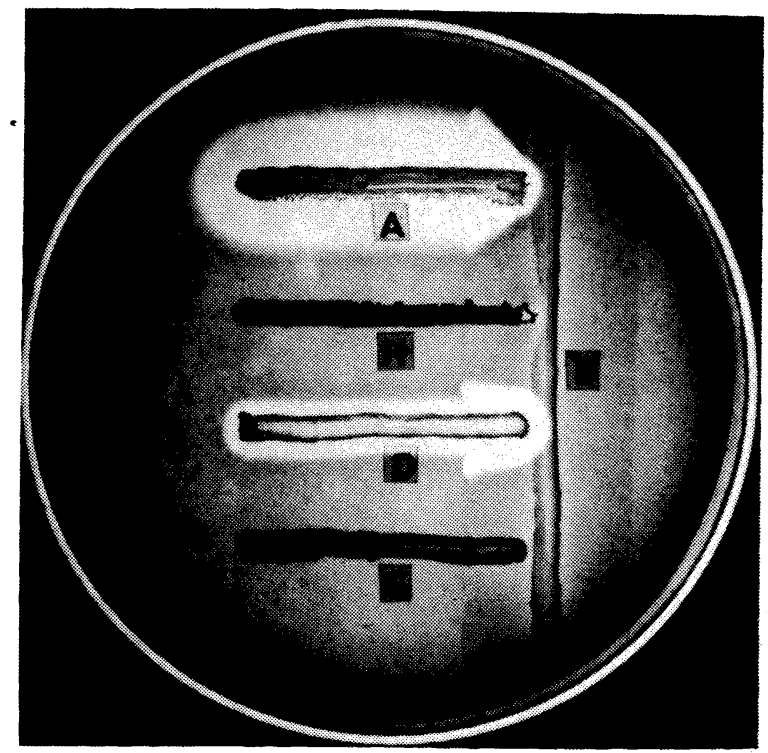

Fig. 1. Agar with sheep erythrocytes (S). Vertical streak of S. aureus producing beta-hemolysin (B). Horizontal streaks: S. aureus producing alpha-toxin (A); S. hyicus (H); S. aureus producing delta-hemolysin (D); $\mathrm{S}$. chromogenes (C). Effects after $48 \mathrm{~h}$ incubation.

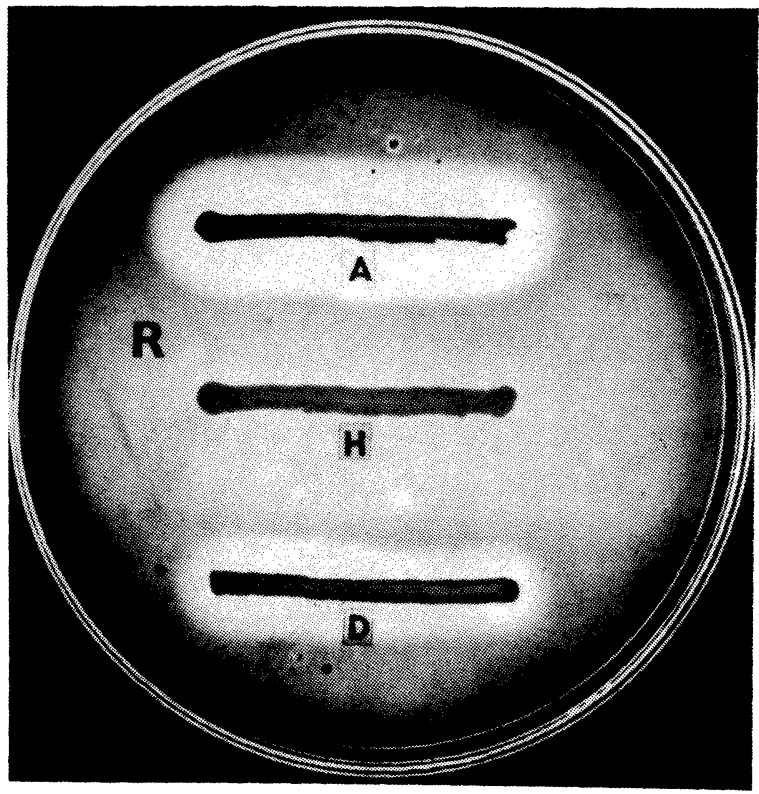

Fig. 2. Agar with rabbit erythrocytes (R). Streaks of growth: S. aureus producing alpha-toxin (A); S. hyicus (H); S. aureus producing delta-hemolysin (D). Hemolysis after $24 \mathrm{~h}$ incubation. 


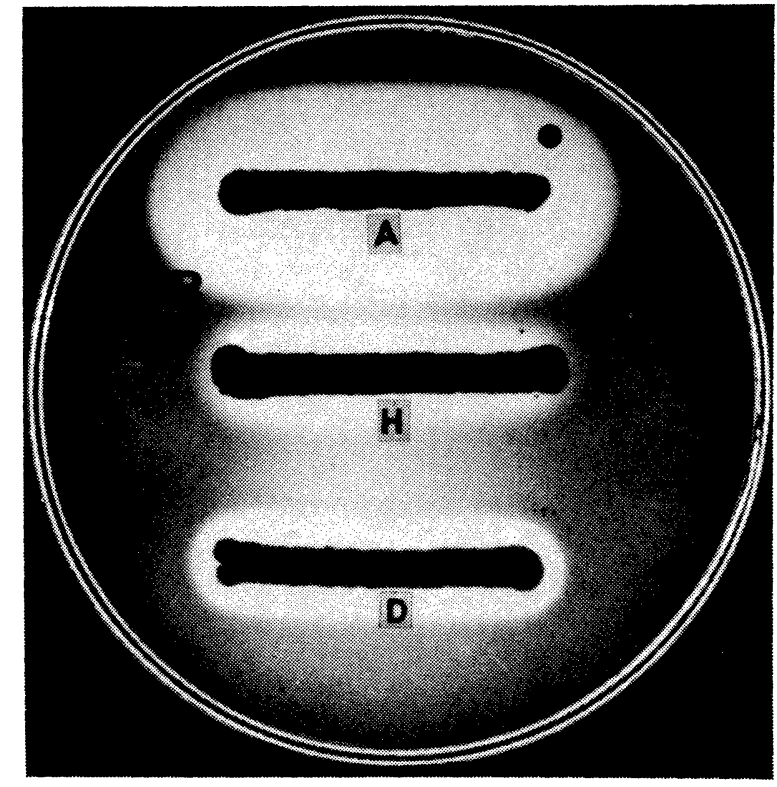

Fig. 3. Agar with rabbit erythrocytes (R). Streaks of growth: S. aureus producing alpha-toxin (A); S. hyicus (H); S. aureus producing delta-hemolysin (D). Hemolysis after $48 \mathrm{~h}$ incubation.

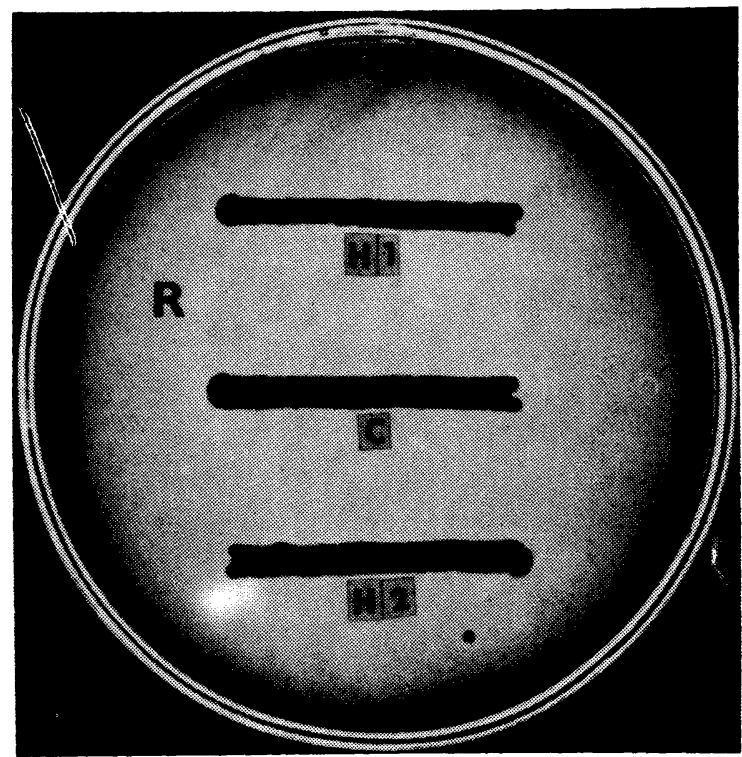

Fig. 4. Agar with rabbit erythrocytes (R). Streaks of growth: two different strains of $\mathrm{S}$. hyicus (H 1; H 2); S. chromogenes (C). Growth after $24 \mathrm{~h}$ incubation. 


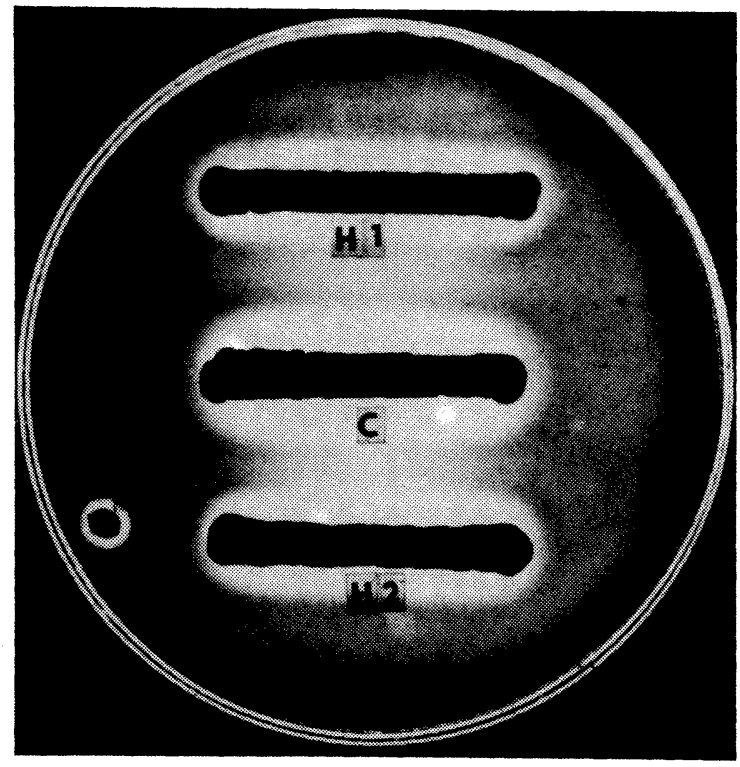

Fig. 5. Agar with rabbit erythrocytes (R). Streaks of growth: two different strains of S. hyicus (H 1; H 2); S. chromogenes (C). Hemolysis after $48 \mathrm{~h}$ incubation.

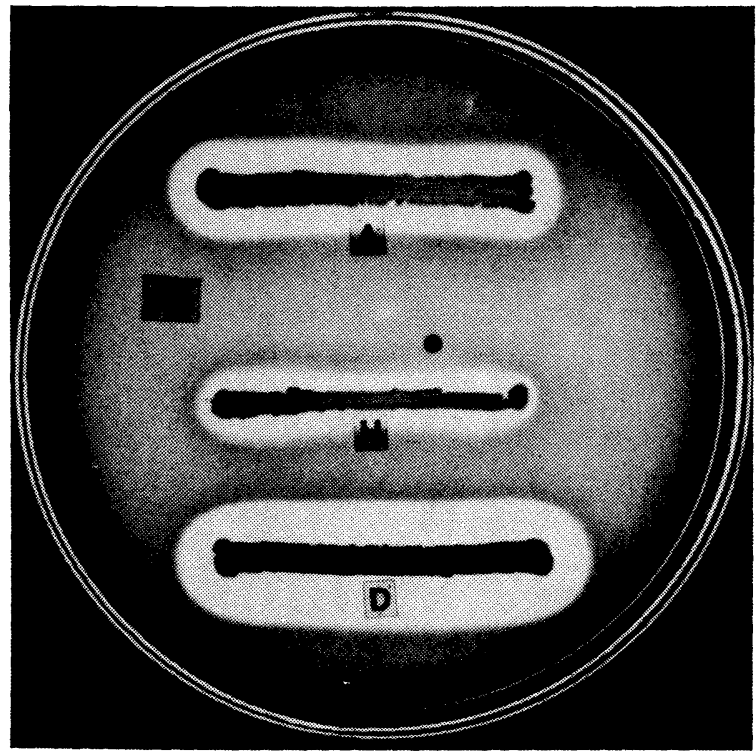

Fig. 6. Agar with human erythrocytes (M). Streaks of growth: S. aureus producing alpha-toxin (A); S. hyicus (H); S. aureus producing delta-hemolysin
(D). Hemolysis after $48 \mathrm{~h}$ incubation. 


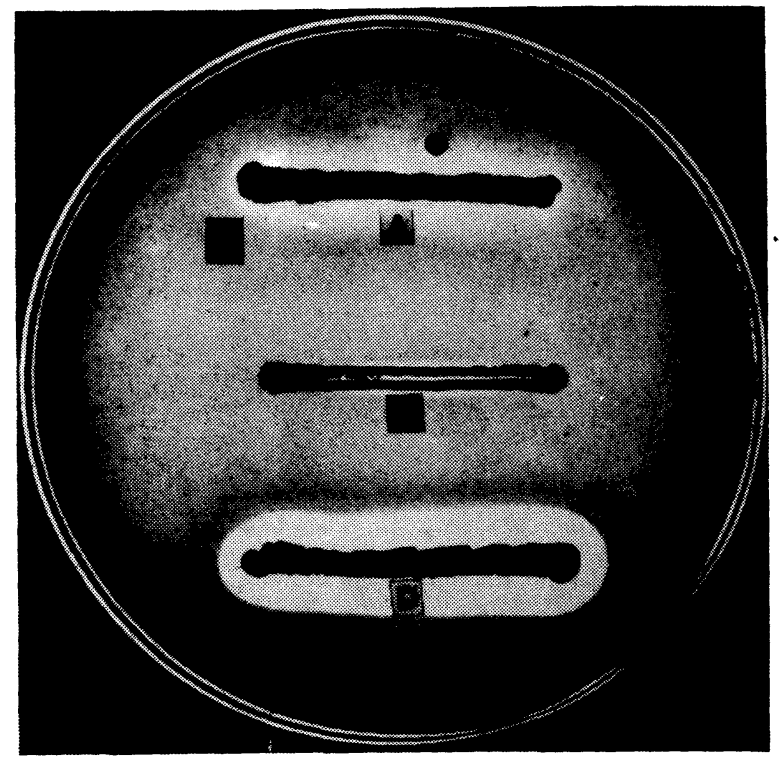

Fig. 7. Agar with horse erythrocytes (E). Streaks of growth: S. aureus producing alpha-toxin (A); S. hyicus (H); S. aureus producing delta-hemolysin (D). Hemolysis after $48 \mathrm{~h}$ incubation.

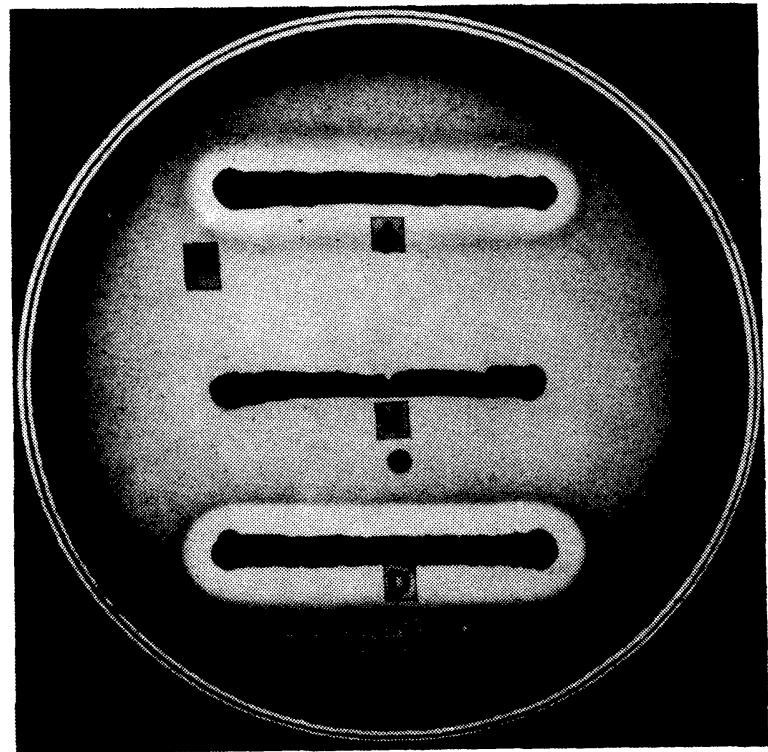

Fig. 8. Agar with poultry erytnrocytes (P). Streaks of growth: S. aureus producing alpha-toxin (A); S. hyicus (H); S. aureus producing delta-hemolysin (D). Hemolytic effects after $48 \mathrm{~h}$ incubation. 
was confirmed by us in the present paper. In addition, we did not observe a marked hemolytic effect when strains of both species were assayed on sheep erythrocytes treated by staphylococcal beta-toxin. A positive synergistic hemolysis of $\underline{S}$. hyicus and $\underline{S}$. chromogenes was described ( $H$ é b e $r$ t and $\mathrm{Hanc}$ o c k 1985; W a t $\mathrm{s}$ and $\mathrm{O}$ we $\mathrm{n} \mathrm{s}$ 1987), and the authors took for granted the production of delta-hemolysin ( $\mathrm{H}$ é $\mathrm{b}$ e $\mathrm{r} t$ and $\mathrm{H}$ a $n \mathrm{c}$ o $c k$ 1985)

or of cytolysin, which acts synergistically with $\underline{S}$. aureus beta-toxin ( $\mathrm{W}$ a $\mathrm{t} t \mathrm{~s}$ and $\mathrm{O} \mathrm{w}$ e $\mathrm{n} s$ 1987), by some strains of both species. A narrow zone of incomplete clearing around streaks of some strains under study, observed by us in synergistic hemolytic assays, resembles the description of D e v r i e s e (1977), who described as hemodigestion the direct effect of some $\mathbf{S}$. hyicus strains on sheep blood agar, explaining it as a consequence of strong proteolytic activity. A close relation of proteolytic activity and the clearing phenomenon observed by us could not be shown, because even some non-proteolytic $\underline{S}$. hyicus strains showed this phenomenon. On the contrary, a great number of proteolytic strains did not produce it.

The use of rabbit erythrocytes in the detection of hemolytic properties of $S$. hyicus and $S$. chromogenes has not been previously described. These red blood cells were hemolyzed by all strains of the both species, and the hemolysis appeared generally after $48 \mathrm{~h}$ of incubation. Such delayed hemolysis distinguishes $\underline{S}$. hyicus and $\underline{S}$. chromogenes from the alpha-

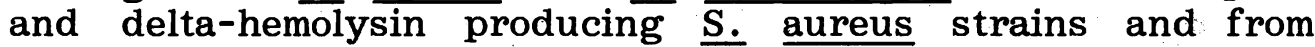
the coagulase-negative staphylococci with hemolytic properties. Strains of these groups always produce hemolysis on rabbit blood agar just after $24 \mathrm{~h}$ incubation.

The effects whown by the control organisms on media containing sheep, rabbit, human, horse, and poultry erythrocytes corresponded with the characteristic activity of staphylococcal hemolysins alpha and delta ( $C$ o $\quad o$ p e $r$ et al. 1962; J a c k s o $\mathrm{n} \mathrm{1962;} \mathrm{B} \mathrm{e} \mathrm{r} \mathrm{n} \mathrm{h}$ e i m e $r$ 1965; $\mathrm{B}$ e $\mathrm{r} \mathrm{n} \mathrm{h}$ e i m e r et al. 1968; W i s e m a $\mathrm{n}$ and C a i r d 1968; $W$ i s e m a $n$ 1975). The hemolysis of $\underline{S}$. hyicus and $\underline{S}$. chromogenes resembled the activity of staphylococcal gamma-hemolysin ( $\mathrm{J}$ a $c k$ s o $n$ 1962; Guyonnet and P $10 \mathrm{~m} \mathrm{~m}$ e $1970 ; \quad M \circ 11 \mathrm{~b}$ y and $\mathrm{W}$ a d $\mathrm{s} t \mathrm{r} \ddot{\mathrm{o}} \mathrm{m}$ 1971; $\mathrm{F}$ a $\mathrm{ck}$ r e 1 and $\mathrm{W}$ i s e $\mathrm{m}$ a $\mathrm{n}$ 1976). The production of gamma-hemolysin by $\underline{S}$. hyicus and $S$. chromogenes was described (G o o d f e $110 \mathrm{w}$ et al. $1 \overline{987})$. But gamma-hemolysin produces a complete hemolysis 
of sheep erythrocytes and its activity is apparently inhibited by agar ( $J$ a $c k s$ o 1962). The nature of hemolytic activity of $\underline{S}$. hyicus and $\underline{S}$. chromogenes, described in the present study, thus remains to be explained, although relation to the staphylococcal gamma-hemolysin is perhaps possible.

The strains previously non-allocated to $\underline{S}$. hyicus because of their failure to produce hyaluronidase displayed hemolytic patterns like those of $\underline{S}$. hyicus. We suggest that these strains are $S$. hyicus and presume that a limited number of hyaluronidase-negative strains exists in this species.

The hemolytic activity of $\underline{S}$. hyicus and $\underline{S}$. chromogenes on rabbit blood agar is a useful contribution to identification of both staphylococal species, and we recommend inclusion of the hemolysis of rabbit erythrocytes among the characteristic properties of $S$. hyicus and $S$. chromogenes. We propose that the hemolyses described in this paper are important markers of $\underline{S}$. hyicus and $\underline{S}$. chromogenes.

Hemolytická aktivita Staphylococcus hyicus a Staphylococcus chromogenes

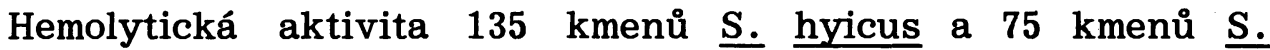
chromogenes se sledovala na krevních agarech $s$ ovčími, králičími, lidskými, koñskými a aviárními (kur domácí) erytrocyty. Agarové medium obsahovalo vždy $5 \%$ propraných erytrocytů příslušného druhu. Všechny kmeny obou sledovaných stafylokokových druhů hemolyzovaly intenzívně králičí erytrocyty a jen velmi slabě koňské. Hemolýzy byly zřetelné vždy až po $48 \mathrm{~h}$ inkubaci při $37^{\circ} \mathrm{C}$. Na krevních agarech $s$ ovčími a aviárními erytrocyty vyrůstaly kmeny obou sledovaných stafylokokových druhů bez náznaku hemolýzy, která se na mediích s ovčími krvinkami nepozorovala ani $v$ testu synergismu se stafylokovým beta hemolyzinem. $\mathrm{Na}$ krevních agarech $\mathrm{s}$ lidskými erytrocyty hemolyzovalo 92 (68 \%) kmenů $\underline{S}$. hyicus, ostatní kmeny tohoto druhu byly nehemolytické, stejně jako všechny kmeny $S$. chromogenes. Kontrolně použité kmeny $\underline{S}$. aureus, produkující hemolyziny alfa, nebo delta, hemolyzovaly na všech krevních agarech již po $24 \mathrm{~h}$ inkubaci, stejně jako hemolytické kmeny koaguláza negativních stafylokoků. Vyslovuje se doporučení zahrnout prolongovanou hemolytickou aktivitu na krevních agarech s králičími erytrocyty do komplexu charakteristických vlastností S. hyicus a $\underline{\text { S. chromogenes. }}$ 
Гемолитическая активностъ Staphylococcus hyicus и Staphylococcus chromogenes

Гемолитическую активностъ 135 штаммов S. hyicus и 75 штаммов S. chromogenes исследовали на агарах крови овец, кроликов, человека, лошадей и птиц. Агар содержал всегда 5\% промытых эритроцитов соответствующего вида. Все штаммы обоих исследуемых стафилококковых видов интенсивно гемолизировали агары кроликов, весъма слабо агары лошадей. Гемолиз отчетливо выделялся всегда через 2 суток после инкубации. На овечъих и птичъих агарах крови вырастали штаммы обоих видов без признаков гемолиза, не наблюдаемого в случае агара овец даже в тесте синергизма со стафилококковым бета-токсином. На агарах С человеческими эритроцитами был установлен гемолиз 68\% штаммов $\underline{\mathrm{S}}$. hyicus, осталъные штаммы данного вида отличалисъ агемолитичностъю как

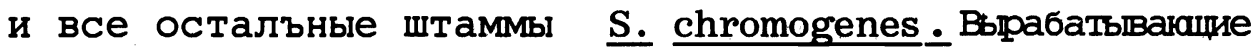
гемолизины алъфа или делъта контролъные штаммы S. aureus јгемолизировали на всех агарах үже через 1 сүтки после инкубации как и штаммы коагулазо негативных стафилококков. Рекомендуется включитъ продленную гемолитическую активностъ на агарах крови кроликов в комплекс характерных свойств $\underline{\text { S. }}$ hyicus и $\underline{\text { S. chromogenes. }}$.

$R$ e $f$ e $r$ e $n$ e $s$

ADAMCZYK, B. - BLAUROCK, G.: Zum Nachweis spezifischer Staphylokokkenhämolysine. Z. ges. Hyg., 9, 1963: 456 - 471 .

BAIRD-PARKER, A. C.: The classification of staphylococci from world-wide sources. J. Gen. Microbiol., 38, 1965: 363 - 387.

BERNHEIMER, A. W.: Staphylococcal alpha-toxin. Ann. N. Y. Acad. Sci., 128, 1965: 112 - 123.

BERNHEIMER, A. W. - AVIGAD, L. S. - GRUSHOFF, P.: Lytic effects of staphylococcal alpha-toxin and delta hemolysin. J. Bacterio1., 96, 1968: 487 - 491.

BOYCE, J. M.: Detection of synergistic hemolytic activity of Staphylococcus aureus with the Cathra replicator. J. Clin. Microbio1., 21, 1985: 835 837.

CHRISTIE, R. - GRAYDON, J. J.: Observations on staphylococcal haemolysins and staphylococcal lipase. Aust. J. Exp. Biol. Med. Sci., 19, 1941: 9 - 16. COOPER, L. Z. - MADOFF, M. A. - WEINSTEIN, L.: Hemolysis of rabbit erythrocytes by purified staphylococcal alpha-toxin. I. Kinetics of the lytic reaction. J. Bacteriol., 87, 1964: 127 - 135.

DEVRIESE, L. A.: Isolation and identification of Staphylococcus hyicus. Amer. J. Vet. Res., 38, 1977: 787 - 792 . 
DEVRIESE, L. A. - HAJEK, V. - OEDING, P. - MEYER, S. A. - SCHLEIFER, K. H. : Staphylococcus hyicus (Sompolinsky, 1953) comb. nov. and Staphylococcus hyicus subsp. chromogenes subsp. nov. Int. J. Syst. Bact., 28, 1978: 482 - 490.

FACKRELL, H. B. - WISEMAN, G. M.: Properties of the gamma haemolysin of Staphylococcus aureus "Smith 5 R". J. Gen. Microbiol., 92, 1976: 11 - 24.

GOODFELLOW, M. -HARWOOD, C. R. - NAHAIE, M. R.: Impact of plasmids and genetic change on the numerical classification of staphylococci. $\mathrm{Zbl}$. Bakt. Hyg. A 266, 1987: 60 - 85.

GUYONNET, F. - PLOMMET, M.: Hemolysine gamma de Staphylococcus aureus: purification et proprietés. Ann. Inst. Pasteur (Paris), 118, 1970: 19 - 33.

HÁJEK, V. - DEVRIESE, L. A. - MORDARSKI, M. - GOODFELLOW, M. - PULVERER, G. - VARALDO, P. E.: Elevation of Staphylococcus hyicus subsp. chromogenes (Devriese et al., 1978) to species status: Staphylococcus chromogenes (Devriese et al., 1978) comb. nov. System. App1. Microbio1., 8, 1986: 169 $-173$.

HÉBERT, G. A. - HANCOCK, G. A.: Synergistic hemolysis exhibited by species of staphylococci. J. Clin. Microbio1., 22, 1985: $409-415$.

JACKSON, A. W.: Staphylococcal gamma-lysin and its differentiation from delta-1ysin. VIIIth Int.Congr. Microbio1., Abstracts, 1962: 111.

KLOOS, W. E. - SCHLEIFER, K. H.: Genus IV. Staphylococcus Rosenbach 1884, p. 1013 - 1035. In: SNEATH, P. H. A. - MAIR, N. S. - SHARPE, M. E. - HOLT, J. G. (ed.): Bergey's manual of systematic bacteriology. 1st ed., Vol. II. Williams and Wilkins. Baltimore, London, Los Angeles, Sydney. 1986. p. 965 - 1595.

MARKS, J. - VAUGHAN, A. C. T.: Staphylococcal delta haemolysin. J. Pathol. Bacterio1., 62, 1950: 597 - 615.

MÖLLY, R. - WADSTRÖM, T.: Separation of gamma hemolysin from Staphylococcus aureus "Smith $5 \mathrm{R}$ ". Infect. Immun., $\underline{3}$, 1971: 633 - 635 .

SKALKA, B.: Ecology and diagnostics of Staphylococcus hyicus (orig. in Czech). Veterinářstvi, 37, 1987: 201 - 203.

SKALKA, B. - SMOLA, J. - PILLICH, J.: Diagnostic U.lization of hemolytically active exosubstances of certain Gram positive bacteria. I. Detection of staphylococcal hemolysins with prepurified preparations of staphylococcal beta-toxin and CAMP-factor of Streptococcus agalactiae. J. Hyg. Epidemiol. Microbiol. Immuno1. (Prague), 23, 1979a: 407 - 416.

SKALKA, B. - SMOLA, J. - PILLICH, J.: Simple method of detecting staphylococcal hemolysins. Zb1. Bakt. Hyg., I. Abt. Orig. A 245, 1979b: 283 - 286.

SKALKA, B. - SMOLA, J. - PILLICH, J.: Diagnostic utilization of hemolytically active exosubstances of certain Gram positive bacteria. II. Detection of staphylococcal hemolysins by means of a prepurified hemolytically active exosubstance of Corynebacterium pseudotuberculosis. J. Hyg. Epidemiol. Microbio1. Immuno1. (Prague), 24, 1980: 36 - 41.

SOMPOLINSKY, D.: De 1 'impetigo contagiosa suis et du Micrococcus hyicus $n$. sp. Schweiz. Arch. Tierheilkd., 95, 1953: $302-309$.

SOUCEK, A. - MICHALEC, Z. - SOUČKOVA, A.: Enzymic hydrolysis of sphingomyelins by a toxin of Corynebacterium ovis. Biochim. Biophys. Acta, 144, 1967: 180 - 183 .

WATTS, J. L. - OWENS, W. E.: Synergistic hemolysis associated with coagulase-negative staphylococci isolated from bovine mammary glands. J. Clin. Microbiol., 25, 1987: 2037 - 2039.

WISEMAN, G. M.: The hemolysins of Staphylococcus aureus. Bacteriol. Rev., 39, 1975: 317 - 344 .

WISEMAN, G. M. - CAIRD, J. D.: Phospholipase activity of the delta hemolysin of Staphylococcus aureus. Proc. Soc. Exp. Biol. Med., 128, 1968: 428 - 430. 